\title{
Explaining Water Pricing through a Water Security Lens
}

\author{
Paula Cecilia Soto Rios ${ }^{1,2, *(1)}$, Tariq A. Deen ${ }^{1}$, Nidhi Nagabhatla ${ }^{1,3}$ and Gustavo Ayala 4 (i) \\ 1 Institute for Water, Health and Environment, United Nations University, 204-175 Longwood Road South, \\ Hamilton, ON L8P 0A1, Canada; tariq.deen92@gmail.com (T.A.D.); Nidhi.Nagabhatla@unu.edu (N.N.) \\ 2 Graduate School of Life Sciences, Tohoku University, Aoba-ku, Sendai 980-8578, Japan \\ 3 School of Geography and Earth Science, McMaster University, 1280 Main Street West, Hamilton, \\ ON L8S 4L8, Canada \\ 4 Ministry of Environment and Water, 20 de Octubre St. 1628 San Pedro, La Paz, Bolivia; \\ gustavo_ayala_t@hotmail.com \\ * Correspondence: paulaceciliasoto@hotmail.com
}

Received: 8 July 2018; Accepted: 27 August 2018; Published: 1 September 2018

\begin{abstract}
Can water security serve as a platform for developing a long-term solution to ongoing water crises? Many regions around the world are experiencing severe water problems, including water scarcity, water-borne diseases, water-related natural hazards, and water conflicts. These issues are expected to increase and intensify in the future. Both developed and developing economies face a water supply and demand imbalance that will potentially influence their water pricing structures. Institutions and policies that govern the pricing of this natural capital remain crucial for driving food production and providing services. The complex and multifaceted issues of sustainable water management call for a standard set of tools that can capture and create desired water security scenarios. Water pricing is an important contributing factor for achieving these scenarios. In this paper, we analyze how water pricing can be used as a tool to enact the water security agenda. This paper addresses these issues from three facets: (1) Economic aspects-the multiple processes through which water is conceptualized and priced; (2) analysis of water pricing considering its effect in water consumption; and (3) arguments for assessing the potential of water pricing as a tool to appraise water security.
\end{abstract}

Keywords: water security; water pricing; sustainable water management; trends and patterns; economics

\section{Introduction}

Water is a crucial and valuable global resource, and its sustainable use is one of the most important challenges of our time. Unfortunately, water will soon be considered a scarce commodity as demand, driven by pressures of economic and population growth and the impacts of climate change, exceeds availability [1]. Among several definitions of water security available in the literature [2], we require a specific framework in which we can analyze water as a commodity, linking water to its price (the price of its access and distribution to consumers) and social good (the necessity for universal access). The definition provided by The Hague Ministerial Declaration described water security as: Ensuring that freshwater, coastal, and related ecosystems are protected and improved; that sustainable development and political stability are promoted, that every person has access to enough safe water at an affordable cost to lead a healthy and productive life, and that the vulnerable are protected from the risks of water-related hazards [3]. Under this definition, discussion regarding water pricing as a tool to achieve the objectives of sustainable development (affordable cost) can be created, considering not only 
the water resources sector but also different socioeconomic aspects. However, utilizing water pricing as a tool to specifically manage water demand can dangerous when considering the unstable political situations some developing countries have suffered by insulated pricing policies. Water pricing as a tool must therefore be analyzed so that not only the tool itself, but also a set of other strategies, are placed into action to acknowledge the complexity of the socio-hydrological relationship. The scale of this research considers national policies that can be applied at the local level, such as for cities and specific industrial and productive sectors within a country.

The United Nations defines water security as: The capacity of a population to safeguard sustainable access to adequate quantities of acceptable quality water for sustaining livelihoods, human well-being, and socio-economic development, for ensuring protection against water-borne pollution and water-related disasters, and for preserving ecosystems in a climate of peace and political stability [4]. Along with this definition, UN-Water also developed a conceptual framework (Figure 1) outlining eight key aspects that form the larger nexus of water security with respect to good governance, drinking water and human well-being, transboundary cooperation, ecosystems, financing, water-related hazards and climate change, peace and political stability, and economic activities and development. These aspects represent two dimensions: a core (key) with the elements under the control of local and regional authorities within a country, and a boundary (enabling) that reflects the external links governments need to carry out in order to advance national plans in the field of water management. This is a cyclical feedback loop, reflecting inter-dependence and interconnectivity among aspects such as governance, financing, peace, and political stability, and issues that extend beyond national borders with issues such as shared water systems and hydro-diplomacy [5]. The usefulness of this framework, for our purposes, is that the UN definition tackles water security with different levels of interventions.

The water security framework highlights the critical importance of an interdisciplinary approach if truly sustainable water management is to be achieved. The financial aspects of water management have gained significant attention in recent years as a method to tackle economic and societal interdependence [6,7]. Whereas water pricing has been long viewed from a supply standpoint, there has been a shift to use demand management as a tool for potentially achieving the water security agenda, as it acknowledges the unsustainable use of water and promotes the necessity of water conservation [8,9]. Given the growing threat of water insecurity [10], the narratives of water necessity versus desirability also need re-examination.

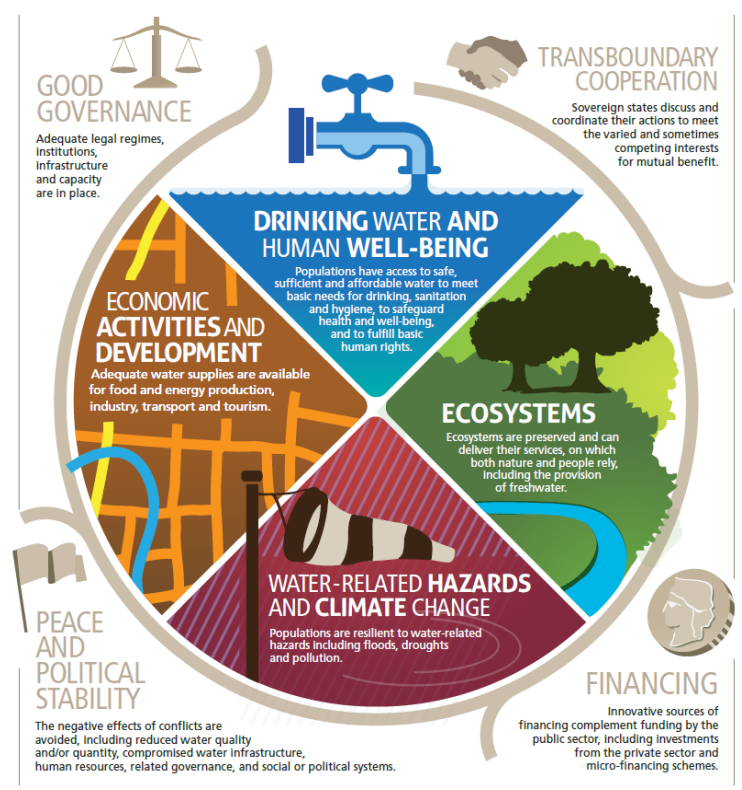

Figure 1. United Nation (UN)-Water's conceptual framework [11]. 
Achieving water security remains critical to meeting the water aspect of the Sustainable Development Goals (SDGs). Numerous alternatives have been studied to reduce water use, and several utilities service providers across the world are making strong efforts to advance water conservation [12-14] not only in the urban water sector but also the agriculture sector. Research has focused on the agricultural sector to improve water use efficiency (another water security tool). It is anticipated that conceptual, empirical, and case study approaches on water pricing could serve as a smart strategy to ensure long-term water security. The discussions presented in this paper explain how a utility service provider (private or public) can employ water pricing policies to encourage customers (users) to manage consumption, maintain financial viability, and promote the mindset of water conservation. In this sense, allocations should account for actual water use and could be adaptable to changes caused by other water security strategies-like water use efficiency-to prevent and manage as many aspects as possible of the increase in water demand [15].

This paper is structured into the following sections: (1) how water is conceptualized and priced, in which we describe the importance of the characteristics of water as a good, and the implication of its human rights aspect (i.e., universal access), which, in many cases, generates misunderstandings between society and policy makers when discussing the price to access water; (2) We then analyze water pricing considering its effect on water demand, in which we provide a summary of sectoral and temporal dynamics regarding the application of water pricing (e.g., price structure variation for agricultural sector and drinking water sector), and spatial aspects (e.g., the availability of resources). In order to evaluate the performance of water pricing policies already applied, we summarize five case studies, two from the agricultural sector, and three from the urban drinking water sector (two from a water scarce perspective, and one from an economic and water plentiful perspective); (3) Finally, we critically analyze the potential of water pricing as a tool for water security, in which we analyze the aforementioned study cases and establish tradeoffs in water pricing as a tool to regulate water demand, while also evaluating the consideration of water a good (special economic good) in outcomes from the applied case studies' policies. The paper concludes with a summary of all previously discussed points and describes how water pricing could be used as a tool to ensure water security objectives given the framework (UN-Water approach) we outline, considering the scale and level of application stablished at the beginning of the paper.

\section{Materials and Methods}

The complexity of applied water pricing policy reflects the efforts of governments and utility service providers put into effect actions that will address water demand. Thus, we completed a systematic review of academic and grey literature on the subject. During our review, we accessed 112 studies, with 40 being excluded due to their irrelevance to objective of this paper.

For the case studies, agriculture and urban water consumption were considered for analysis because of their complexity and diversity with respect to water pricing. Both national and municipal/district level examples were chosen. The paper focuses on the agriculture and urban drinking water sectors because $86 \%$ of the total global water consumption is due to agricultural activities [16] and given the importance urban water access to societal development.

\section{Managing Water Resources: Conceptualization and Pricing Structures}

\subsection{Water as a "Good"}

In 1992, the Fourth Dublin Principle established under principle (1) and (4) that water is a finite and vulnerable resource that has an economic value and should be recognized as an economic good [17]. In addition to this, the Rio Principle expressed that water is a social good and that humans are entitled to, at least, a minimal quantity and quality of safe water. However, the emerging pluralism in the valuation and interpretation of water could lead to scenarios of competing and conflicting conceptualizations. The emerging concepts influence the existing debate by experts from various 
disciplines over water pricing. When water is priced as an economic good, its economic value can vary depending on buyer and seller willingness to pay [18]. However, if the concept of social good is applied to the pricing structure, then water should be affordable to the poor, benefiting the largest number of people in the best possible way. To add further complexity with respect to the economic principles, the true "economic" value of a good and its "financial" value seldomly correspond; hence, the competitive market prices reflect only the financial and not necessarily the economic values of water [19].

Briscoe [20] tried to connect the concept of water as an economic good by using water pricing. Figure 2 shows the optimal consumption for water as $X^{*}$, on the left. The graph on the right shows the water consumption when the marginal cost of supply differs from the charged price, then the consumer will not consume $X^{*}$ (optimal consumption) but $\mathrm{X}^{1}$ (new consumption), but still pay price $\mathrm{P}^{1}$ (charged price). The increase in cost (the area under the cost curve) exceeds the increase in benefit (the area under the benefit curve) and there is a corresponding loss of net benefit, called the deadweight loss. However, this concept is only applicable to people who can actually afford the price of water, like any other good. In this context, the deadweight loss is seen as a human gesture of tax-payers who are willing to subsidize water to avoid water poverty. Thus, the supply curve will shift down to the point where it intersects the demand curve at $\mathrm{P}^{1}, \mathrm{X}^{1}$.

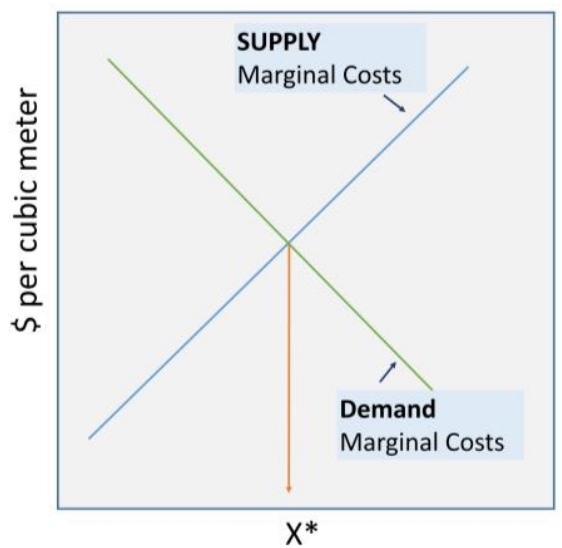

(Cubin meters per year)

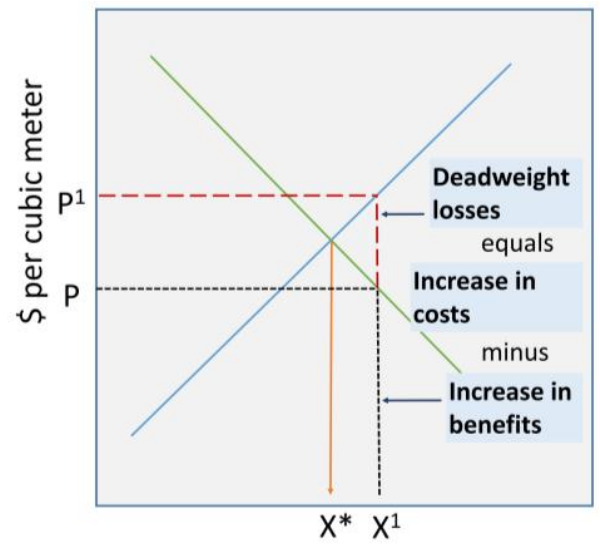

(Cubin meters per year)

Figure 2. Optimal consumption (left) and "deadweight losses" if water is underpriced (right) [19].

From the previous explanation and in order to continue this analysis, we must consider water as a special economic good (discussed below). However, water utilities are usually a natural monopoly and the marginal costs are usually lower than average costs. Such pricing would lead to a unit price that is less than the average cost and the utility will not generate enough funds to cover all costs (operational, management, quality, maintenance, or future events). From this, the question of how to use water pricing as a strategy by using deadweight losses efficiently is answered using two main theories in economics. One theory involves using subsidies and taxation as a form of lump sum transfer to make up the loss as explained before. The second is to use price discrimination to recover costs through Ramsey pricing and Pareto Superior Non-Linear Outlay Schedule [21]. The answer will vary according to different conditions of time and place, especially as conflicts over resources increase values and people's rationale changes.

\subsection{Commodifying the "Good"-Water Pricing Structures}

The application of water pricing declined in the early 2000s due to a social resistance in many countries and the lack of ability of governments to properly implement water pricing structures. Each sector faces challenges with respect to pricing methods, not only between countries but within regions of the same country. Water pricing is considered a crucial issue for decision makers, water 
services providers, and consumers. For this reason, assessing a socially fair average water price that would be acceptable according to the reality of each area is recommended [22,23]. Water security could be severely affected if innovations in water pricing are not developed and implemented. Some efforts, such as the European Union Water Framework Directive (WFD), have been introduced to create structures in which water users' taxation reflects the complexity of valuing the water [24,25].

Water pricing can vary among and within different economic sectors. For example, water pricing within the agricultural context can vary based on agricultural area (i.e., area-based pricing), agricultural output, the value of the land (i.e., betterment levy pricing), or the amount of material used for agricultural production (i.e., input pricing), or pricing can be uniform for all users [26,27]. However, the most basic types of water pricing are: (1) flat rate, which implies no requirement for controlling the demand with the price; (2) uniform (volumetric) rate, which is the basic structure used to put into consideration the value of the quantity of delivered water to the final user; (3) block or tire rate, which is used in order to focus the water consumption in specific values; and (4) complex rate structures, based on behavioral analysis of water users to optimize not only revenues but also water consumption itself [25]. These water pricing structures are illustrated in Figure 3.

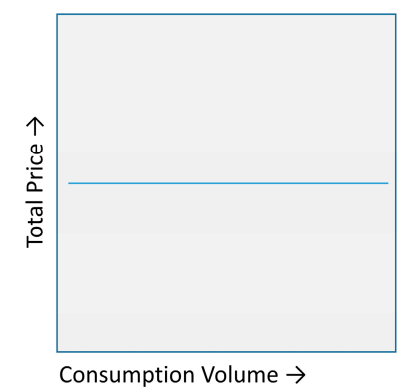

(a) Flat Rate

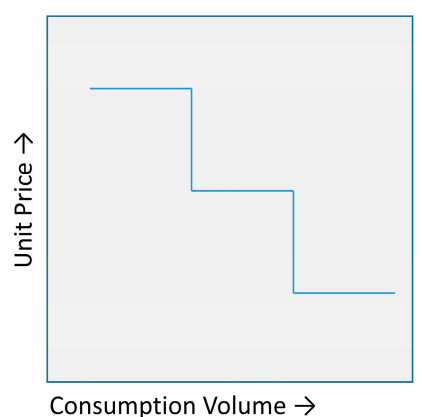

(c) Block or Tire Rate

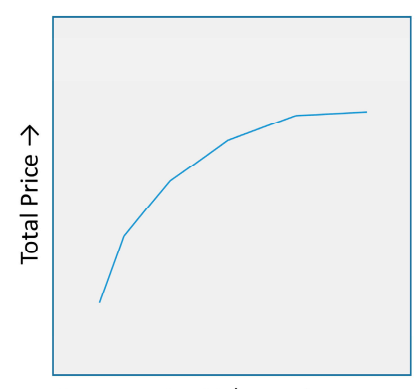

Consumption Volume $\rightarrow$

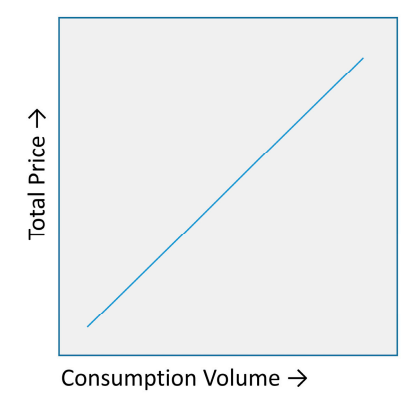

(b) Uniform Volumetric Rate

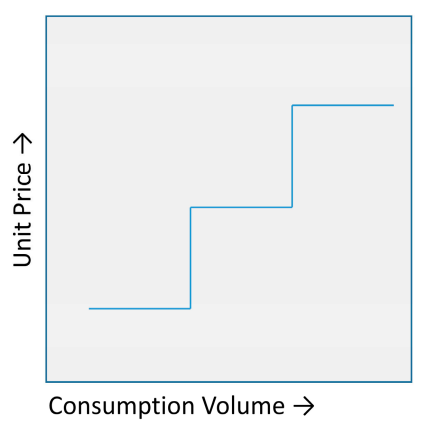

Consumption Volume $\rightarrow$

(d) Complex Rate

Figure 3. Cont. 


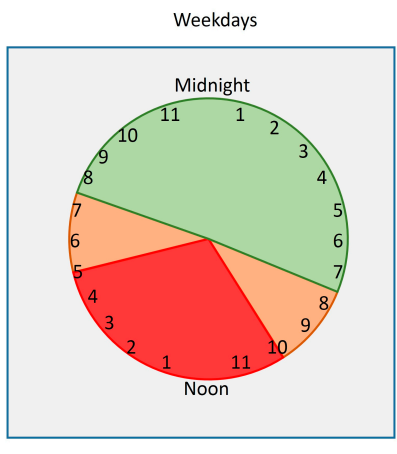

Off-peak (lowest cost)
Weekdays and Holidays/Wet Season

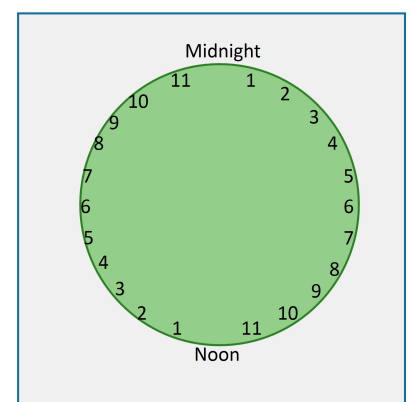

Mid-peak (mid cost)

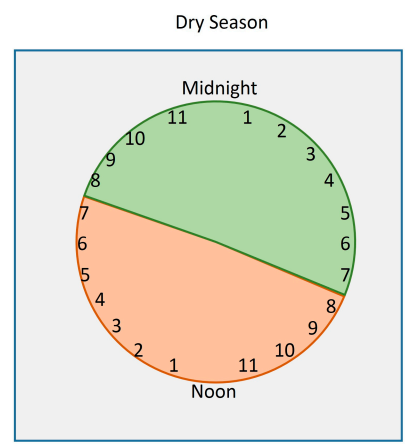

On-peak (highest cost)

(e) Alternative Structures: Time of Day or Seasonal rates.

Figure 3. Overview of water pricing design and structures: (a) All customers pay the same price regardless of the amount they consume; (b) the total price of water is dependent on the amount of water a customer uses. The unit price of water does not change but the total monthly price will change. (c) Customers are charged for water based on increasing (or decreasing) flat rates; i.e., the price of water changes once a limit has been reached. (d) Water price changes once a certain limit has been reached and constantly increases. The total water price will always be different depending on water consumption. (e) Water pricing is adjusted based on the time of day. The unit price of water is higher during peak hours to encourage water conservation; water pricing is adjusted based on climatic conditions, for example, wet and dry season.

\subsection{Models for Water Provisioning}

At the national scale, water resources are managed by different entities: normally public utilities provide urban water services, while irrigation water is managed by irrigation districts, and water pricing in both sectors is under the regulation of different government agencies [28].

For service delivery, there are three basic models: (1) Common property management; (2) municipal companies; and (3) forms of privatization.

Common property management is controlled by the user's group that arranges the delivery and supply of the resource. However, water resources are mostly managed by the public sector (i.e., natural monopoly) to maintain the balance between water conservation and revenue stability in water structures. In other cases, privatization is used as a model to enhance access to water, but for some economists, privatization is no more than a means to create competition, since a monopoly is expected to be inefficient whether it is private or public [29]. In Latin America, some cases of privatization have been a polemical topic, leading to a series of protests and riots when the population was not informed properly [30].

Given these realities of rivalries, externalities, and monopolies, as well as equity considerations, some governments require a higher authority that can establish rules regarding the rights of individual access and management of water. These standards basically refer to the amount (i.e., volume) of water extracted from a primary source and the quality of the water both supplied to the end users and released as a secondary source after its use. Overall, water management (although mostly focused on provision) focuses on determining how much demand for water would inevitably increase in the future and how increased demand will be addressed in different sectors (e.g., agriculture, urban water, commercial, etc.). One of the challenges some governments are facing with respect to the conceptualization of water as a special economic good is to identify who should be responsible for its management considering that almost any intervention in managing water affects the environment, society, and the economy, either intentionally or incidentally [29]. This discussion raises the question of whether water is a special economic good that can be reasonably left to free market forces or if some amount of extra-market management is required to effectively and efficiently serve social objectives [24]. Researchers have considered the complex relationship of promoting water conservation and ensuring a stable revenue 
stream to cover the predominantly fixed charges of running a water utility. They state that, to achieve maximum social efficiency and minimize deadweight losses, the pricing should be at the level of long-run marginal cost [24]. The other challenge is fitting water provision within the overall mandate of sustainable water management.

Van der Zaag and Savenije [31] stated that there is no other economic good that has the complicated characteristics of water. For this reason, water should be called a special economic good that is an essential, non-substitutable resource that needs reasonable pricing structures that aim at cost recovery, and simultaneously ensure access to safe water for the poor, while considering ecological requirements. The future predictions of global water scarcity demands highlight that a reasonable water pricing structure should be assigned that encourages cost recovery and resilience by sending a clear signal to water users that the resource should be used wisely. However, setting appropriate prices depends on water use, making the selection process difficult since the nature of water's cost varies in different economic sectors and geographic locations. For this reason, if water pricing is to be defined as an economic policy intervention tool that can be used to achieve the environmental, social, and economically efficient management of water, then it is essential to understand its implications in real world situations to ensure its applicability as a water security tool.

\section{Analysis of Water Pricing Considering its Effect on Water Consumption}

Water pricing strategies vary between economic sectors and states. For example, pricing of agriculture or urban water could be based on completely different underlying principles. To further understand the use of water pricing as a tool for water security, it is an imperative to explore how the concept is applied.

\subsection{Sectoral and Temporal Dynamics}

Water pricing in the agricultural sector has attracted special interest from researchers and policy makers due to the complexity of water consumption concerning the food security nexus $[8,9]$. Irrigation water supply is often subsidized given that food security and rural livelihood issues take precedence over the cost recovery model [32]. Studies report negative impacts of water pricing on income and agro-production trends due to farmers reducing water consumption by changing crop plants or introducing less profitable crops. Berbel and Gómez-Limón, Elnaboulsi, Kanakoudis et al., and Aidam [33-36] proposed a base-price design through mathematical models (e.g., Linear Programming or Multi-Analysis Tool for the Agricultural, MATA) to establish a tariff that would not negatively affect farmers' income, and in turn encourage saving water by reducing waste and improving efficiency. The MATA model promises a strategy to address potential conflicts to achieve positive results on water rights.

In the urban context, planning water supply methods while employing a based-price design agreement and embedding scenarios with respect to droughts, water stress, or the "incremental cost" of operation creates a challenge for proposing price reforms without polemic consequences or physical conflicts [37]. With this in mind, we selected some case studies to support our argument. Case studies 1 and 2 were selected to analyze the agricultural sector, specifically within the national scale of policy intervention. Case studies 3 and 4 focus on urban water consumption, and the fifth case study exemplifies the importance of water pricing in societies which has both water and resources availability surplus. 


\subsection{Case Studies}

\subsubsection{Irrigation Sector}

Case Study 1: Smart Water Pricing in the African Continent-Ghana

Although the agricultural sector in Ghana has declined over the years [38], but it remains an important contributor to Ghana's export earnings and a major source of inputs to the manufacturing sector and the most important sector for jobs and livelihoods in the rural areas. [39]. Major Ghanaian crops include cocoa, coffee, oil palm, cashew, and rubber [38,40]. During the dry season, Ghanaian farmers rely heavily on irrigation and are the dominant source of water resource consumption in the country $[41,42]$. Reports suggest that the country is experiencing significant water scarcity, especially in the agricultural sector, and poor management of agricultural irrigation pricing has resulted in poor economic returns [43-45]. There are also reports of urban farmers using wastewater for irrigation as an attempt to meet growing demand for vegetables due to inadequate health education [46,47]. Therefore, the need for different systems or an appropriate model to price water in the agricultural sector remains crucial.

Aidam suggested a Multi-Analysis Tool for the Agricultural Sector (MATA) approach to understand the relationship between the farmer's activities and water pricing policy [36]. The model is comprised of different modules and takes note of the behavior of the process for creating agricultural products and the behavior of consumers with a price expectation and risk attitudes, while incorporating the environment in which farmers, processors, and consumers make decisions. Finally, water supply variables are also incorporated to add the impact of water demand on the agricultural sector in Ghana $[36,47]$. This study selected areas according to their resource characteristics (e.g., land, labor, capital, and management) and farmer management decisions were simulated to provide a guideline on water pricing for a homogeneous agricultural sector with identical socio-economic and agro-climatic environments. The principal assumption was income maximization as priority goal for each farmer activities; incomes for each farm were GHф 449,867.00 (USD \$101,550.63) for large farms, GHф 454,081.00 (USD \$102,501.88) for medium farms, and GH $\$ 359,666.00$ (USD \$81,189.13) for small farms. The crops used were rice, maize, and vegetables. If water prices increased significantly, then water pricing policy would have a negative impact on the demand for water resources, resulting in a subsequent reduction in both farmers' income as well as labor employment, thus negatively affecting agricultural and social business. However, after using the MATA tool, it was established that adopting 2 cedi $/ \mathrm{m}^{3}\left(0.43 \mathrm{USD} / \mathrm{m}^{3}\right)$ in that year as the uniform volumetric rate was a measure that both engaged farmers to consciously use less water resources and motivated them to implement water saving technologies.

This analysis provides a different approach to manage water consumption in the sector and focuses on irrigation efficiency. Linstead [15] examined the improvements in irrigation efficiency in environmental services and concluded that allocation of water use should account for actual consumptive use (i.e., irrigation consumption) and should be adaptable to changes over time in irrigation efficiency, i.e., withdrawal or use allocation should decline as the irrigation efficiency increases to prevent overall increases in consumptive use. In this sense, management and planification strategy have a positive effect when water pricing is used as a tool by reducing and regulating consumption growth by MATA modelling, and at the same time ensuring the incentive in the sector remains focused on irrigation efficiency. This allows governments to implement strategies in other sectors, such as the environment, by using the remaining water to improve conditions as a result of the application of these two tools. This non-explicit behavior in the outcomes from the strategies acknowledges the complexity of non-linear water-social response, a characteristic of a water security tool [48]. 
Case Study 2: National Strategies in Water Pricing-Spain

Agriculture production in Spain relies on the $60 \%$ of irrigated areas and only $19 \%$ of cultivated areas; therefore, $80 \%$ of the water supply is consumed by agriculture. The old system for irrigation was flat rate systems imposed by the Comunidades de Regantes (CR). These communities are assigned by the government agencies to manage water; however, farmers are charged only part of the total distribution cost. This fixed cost is calculated by hectare and used to irrigate subsidized extensive crops. Common Agriculture Policy (CAP) is considered detrimental as it causes losses because of the high consumption of water. Berbel and Gómez-Limón [33] applied Linear Programming mathematical modulation by variables and interrelationships into a matrix algebra to better understand the implication on decisions of policymakers and farmer's objectives in annual herbaceous crops (e.g., alfalfa, wheat, etc.) [33]. This study found that, for almost all crops (under CAP), adding a price to water will cause unemployment and negatively affect farmer income, reducing it to $25-40 \%$ before achieving the reduction in water consumption and making the region vulnerable, as farmers would reduce the range of crop production. Berbel and Gómez-Limón simulated that a fixed tariff of $2 \mathrm{Ptas} / \mathrm{m}^{3}$ (former Spanish currency) could help reduce water consumption and persuade farmers to use water-saving technologies that do not affect the crop [33]. The authors stated that this fixed tariff should be analyzed continuously considering seasonal changes in the consumption and annual income, so the water pricing policy could be implementing properly. In this example, we see the problematic aspects and challenges of applying narrow perspectives (e.g., subsidized policy and flat rate price) given a new national strategy of preserving water resources.

\subsubsection{Urban Water Consumption Sector}

\section{Case Study 3: Incentive-Based Approach—São Paulo, Brazil}

Companhia de Saneamento Básico do Estado de São Paulo S.A. (SABESP) is a Brazilian water and waste management company owned by São Paulo State, considered the largest waste management company in the world by market capitalization, providing water and sewage services. The 2014-2015 drought created a water crisis in Brazil and forced SABESP to implement a subsidy program based on the combination of two forms of incentives to promote sustainable water use. A subsidy was offered to members of the community who reduced their water consumption. By implementing the program, environmental conditions improved and consumers received a government reward (i.e., discount on the water price and sewage tariff). In addition, a contingency fee was imposed on consumers as a form of punishment where an increase in demand was noted. This was implemented in the through taxes, fees, and high charges per unit (Figure 4).

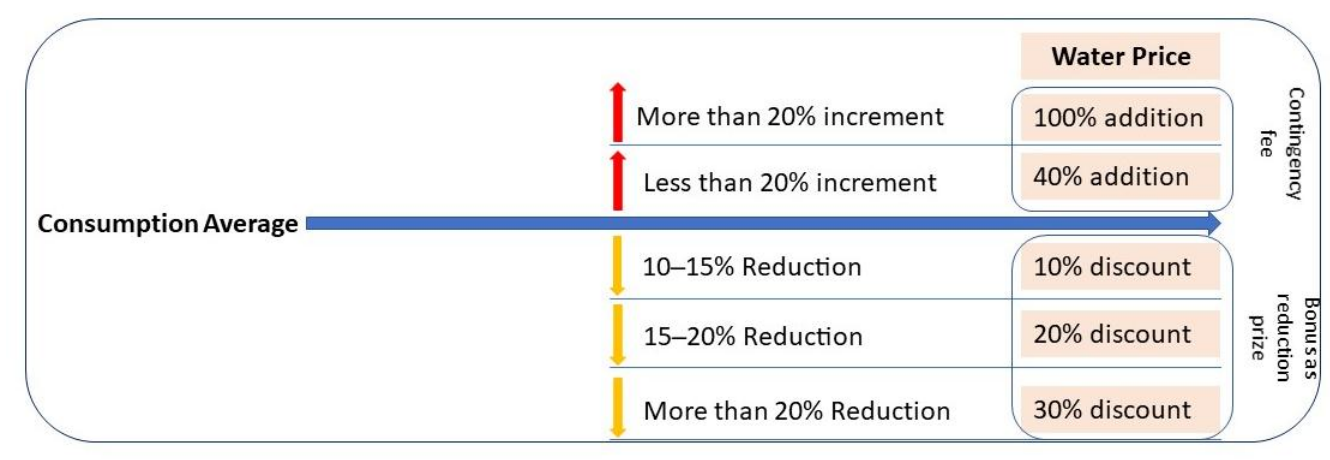

Figure 4. Companhia de Saneamento Básico do Estado de São Paulo S.A (SABESP) program to reduce overconsumption of water [49].

In 2016, the City of Machado evaluated the effectiveness of SABESP's program. The study took the average consumption of water per household during the period of 2013 to 2015 covering 25 districts 
of the municipality. The dependent variable analyzed was the reduction in water consumption. An increase in average residential consumption in all districts between January 2013 and January 2014 was observed. In contrast, between January 2014 and January 2015, the average reduction in this period was $25.0 \%$, with a median of $25.98 \%$ attributed to an "awareness effect" as a function of the serious water crisis experienced. According to Gilbertson et al. [45], attitudes and behaviors in relation to water conservation in households differ between regions and are based geographically $[49,50]$. However, in the case of São Paulo, even in the described scenario, households received water because of SABESP's program, whereas households of other municipalities in the region were affected by the water crisis [49]. The strategy used by SABESP is similar to what is called Hybrid Policy, through which subsidy and taxation systems are implemented at the same time based on consumption patterns and trends. However, the success of SABESP during the water crisis was not accomplished by the technical characteristic of the water pricing strategy (the Hybrid Policy) but by the complementary strategies applied in conjunction with the Hybrid Policy. This awareness effect was created by the intensive promotion of water conservation that SABESP deployed in parallel with the Hybrid Policy. Therefore, this case study also illustrates that water policy strategies must work holistically, so they become tools that recognize and manage the complexity of social, political, economic, and climatic dimensions [51], which are characteristics of water security under our framework.

Case Study 4: Water Pricing and Conflict—Cochabamba, Bolivia

The privatization of Cochabamba's water utilities was initiated by the World Bank, and the International Monetary Fund (IMF). The privatization agreement was the result of a three-year, USD \$138 million national debt relief program from the IMF [52]. Following privatization, a private international consortium (Aguas del Tunari) elevated water premiums by as much as $60 \%$ for some consumers [53], resulting in months of protests, hundreds injured, and at least six dead. The protests concluded with the President agreeing to a concession and returning water ownership to the municipal authorities [54-56]

Prior to privatization, Cochabamba's water services were owned and operated by the Municipal Water and Sewage Service of Cochabamba (SEMAPA). Under SEMPAPA's ownership, only $50.20 \%$ of residents were connected to municipal water, with many people relying instead on public and private wells, cistern trucks, springs, and neighbors as alternative sources of water [52]. The privatization agreement was believed to address Cochabamba's significant water scarcity issues in addition to alleviating national debt [52]. The privatization guaranteed a return on investment of at least $15 \%$, thereby justifying Bechtel's (the majority stakeholder in the consortium) approach to increasing water price, resulting in a multiple tier block rate structure [57].

It was argued that the price increase was necessary to reflect service costs and was consistent with other utility contracts in high-risk countries. In addition, the policy was meant to be inclusive, as the price increase among the poor was claimed to be no more than 30\% [50]. However, as Shultz [58] stated, price increases were actually $41 \%$ among the poor and $51 \%$ on average for all users. Many residents felt that the new pricing structure was unfair and unaffordable, resulting in the violent protests and eventually termination of the contract. Despite control returning to SEMAPA, issues of water scarcity have not improved in Cochabamba, as fewer people have access to water than prior to the privatization $[59,60]$.

A key characteristic of the IMF and the World Bank's policy intervention was that it only considered water from an economic perspective. Bechtel and the consortium paid no regard to two crucial elements in the city: the overall lack of water resources, and the spatial component of the water scarcity. The lack of a holistic strategy led to a situation in which it was not the water pricing strategy itself that was inapplicable, but the unilateral policy implementation that considered only a return on investment. 
Case Study 5: Governance Reforms in a Developed Economy-France

In France, urban water services are publicly owned, but operational responsibilities can be given to private operators if public operators cannot meet certain requirements [61]. Although national legislation has had a history of affecting water pricing and management (e.g., the 1992 law), the current water pricing structure is strongly influenced by France's 2006 water law (Loi sur l'eau et les milieux aquatiques; LEMA). Under this law, specifically under article 57, water service providers are forbidden the use of flat water pricing rates and declining water pricing rates (with exception to small cities and water plenty areas). The 2006 law was meant to emphasize water conservation. However, it should be noted that, overall, France has an abundance of surface and groundwater, although certain parts, mainly the south and east regions, experience dry seasonal weather.

Before LEMA, the water pricing structure was mainly uniform volumetric (applied to $57 \%$ of the districts). After the legislation of LEMA, statistics from 2013 show that the number of districts using uniform volumetric pricing systems increased to $61 \%$, and decreasing pricing systems-like flat rate structure-dropped to $4 \%$. Furthermore, the percentage of districts using increasing pricing systems grew from $1 \%$ in 2003 to $29 \%$ in 2013 [62]. The pricing policy reform led to an increase in water efficiency by $3 \%$ from $78 \%$ in 2008 to $81 \%$ in 2010 , and a decline of $4.2 \%$ in the number of lead pipes in the country [63]. Finally, France ensures that water prices remain below the national minimum wage and water utilities have provided grants for low-income families that cannot meet their monthly water usage bill [64].

In the case when there is an ideal situation between demand and supply, water pricing strategies should focus on the optimization of the sector, an aspect that national agencies do not consider at first. In the case of the French government, they chose to optimize their water pricing policies by practical analysis and study of policy effect, which is a characteristic of the water security framework (expanded research agenda) [51].

\section{Potential of Water Pricing as a Tool for Water Security}

As previously described in the case studies, the power of water pricing as a policy of regulation for water consumption is quite relevant, as it implies that, as a water policy, pricing can control the demand sector. Therefore, water pricing is considered a crucial issue for decision makers, water utilities managers, and consumers. Water security can be severely affected if innovations in water pricing are not developed and implemented efficiently to improve and ensure the effectiveness of another strategies already in place. Efforts have commenced to address this issue in some parts of the world. For example, the European Union Water Framework Directive (WFD) created a pricing structure that taxes water users to reflect the scarce value of water [65]. The European Commission report states that water pricing should be used as a key tool to support water management decisions, and that underpriced water may lead to its unsustainable use. The report goes on to state that water pricing should be discussed within social policies to help ensure that they are fair to all sections of society and environmentally sustainable (i.e., ensuring that developing populations do not suffer from high water pricing policies). Applying a participatory approach to water-related decision making is recommended [50]. In contrast, other case examples reflect how water prices could lead to social conflicts and increase government reluctance to adopt this approach, since the different views regarding government's role in water regulation are based on cultures, religions, and political interests [66]. Moreover, negotiation principles demonstrating different and often heavily asymmetric bargaining positions of partners are related to water pricing of existing cross-border utilities [21]. Consequently, to establish whether water pricing could serve as a tool for water security, from the case studies, we concluded that the price of water as a strategy is highly sensitive in societies with problems of scarcity. Therefore, its application must be carefully studied, considering the understanding as well as who is in charge under different scenarios, and commitments of the water allocation, distribution, and overall management. 
Yepes [67] sketched a pricing policy as one that distributes the costs of services among users, which must be designed to achieve the objectives of economic efficiency, using multiple investment and operations to provide an additional unit of service; financial sufficiency. The policy should have the necessary resources for the provision and maintenance of the service in an efficient and sustainable manner, along with the possibility of growing and improving infrastructural investments. The policy should provide universal access for all to the water service with simplicity and transparency [67]. The pricing policy must be understood by all persons involved: users and officials. Regarding transparency, rules must be clear with respect to the allocation of user costs so that they are accepted by society. Hughes [68] explained how revenue sufficiency is the primary financial objective for water utility systems that operate as enterprises and considers the other aspects (stated as below) as secondary objectives.

(1) Affordability: Ensuring that water is affordable to a community for basic services is a priority of many utilities and their governing boards. Maintaining affordable rates should almost never take precedence over charging rates that are necessary to recover the full costs of service.

(2) Conservation promotion: The amount that customers pay for water service acts as a price signal, often encouraging the customers to decrease consumption.

(3) Economic development: Utilities may strive to attract new or maintain existing commercial customers through water rates to foster greater community benefit.

(4) Short-term revenue stability: Year to year, most water utilities rely on revenue from water consumption charges to cover the predominantly fixed costs of the utility. Yet, water consumption can vary and is on the decline for many utilities, undermining water utility revenue stability, which some are calling the new normal.

Considering that the amount of water is finite, and the marginal cost of water can be very high in droughts or when a reservoir runs dry at the end of the season, and once a person (or a crop) receives sufficient enough water to alleviate physical stress and strain, the utility of additional units rapidly falls and becomes negative. To evaluate potential drivers of an efficient water pricing policy as to tool for water security realization, different perspectives-illustrated using the selected case studies-present a fair argument that water pricing can be used either effectively or ineffectively to promote water security. For instance, in the agricultural sector, water pricing draws special interest from the national governments due to the link between production and food security $[8,9]$. There is consensus that water pricing in agro-production and subsistence livelihood sectors report negative trends, referring to impacts like change in cropping composition or introduction of less profitable crops [33].

Kanakoudis et al., Elnaboulsi, and Aidam [22,34,36] outlined a base-price design through mathematical models. The Ghanaian and Spanish case studies exemplify the use of this concept, and modeled evidence to establish a tariff that would not negatively affect the farmers' income that would help encourage saving water through consumption management using the MATA and LP approaches. Whereas models are only reflective of scenarios specific to different contexts and situations, researchers often point towards data gaps [69], showing that you cannot methodologically cover the entire context. Therefore, water pricing policy should not be outlined as a standalone tool but as part of overall water governance measures (i.e., irrigation technology policies) to achieve effective results.

In the municipal context, planning water supply employs a base-price design agreement and embeds scenarios of droughts, water stress, or the incremental cost of operations, making it hard to propose reforms without polemic consequences or physical conflicts [37]. For many municipalities, water accessibility is a persistent issue, as illustrated in the Cochabamba case study. The privatization contract was intended to increase water accessibility in this city, but the consortium failed to assess the stakeholders' economic and social needs (a multidisciplinary framework showed in water security framework, not applied in this case).

However, increasing water rates does not always lead to social unrest, as illustrated in the French case study. Although water pricing structures for many French municipalities changed from flat and 
decreasing pricing structures to volumetric and increasing ones, the average rate of water remained below the national minimum wage. In theory, this approach would allow affordability while promoting water conservation, aligning with national goals of water security. In addition, it allowed for the provision of water subsidies for low-income families, which addressed issues of income inequality.

The new water management policies need to factor in multiple aspects highlighted in the water security nexus. Many regions worldwide are facing natural- and anthropogenic-driven water scarcity, and therefore require smart thinking (nonlinear) in valuing and pricing provisioning services. The case of study in São Paulo presents a good example of a practical strategy to manage demand and consumption that can in turn promote water conservation. Figure 5 illustrates how a smart water pricing policy based on the presented arguments could enable prioritizing policies and approaches dealing with positive and negative spillovers while ensuring water secure futures.

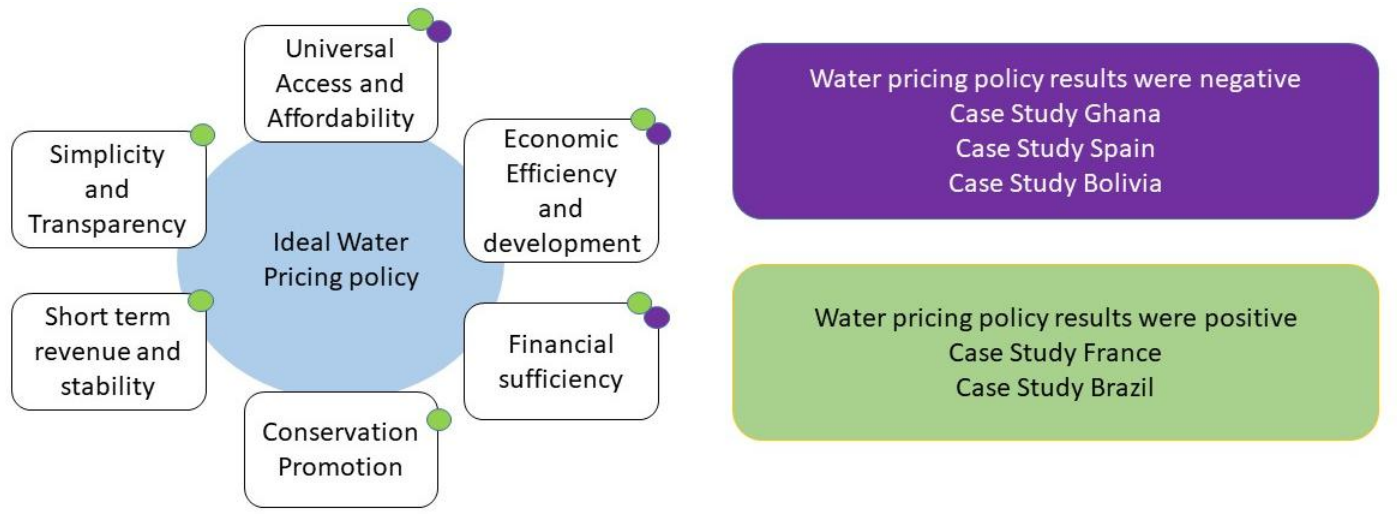

Figure 5. Prioritizing strategies lead to affect positively and negatively water pricing.

Furthermore, Figure 6 exemplifies the water pricing conceptual feedback process at the level and scale analyzed in this study (national and sectorial scale for urban and irrigation sectors) in terms of a water security framework. One of the outcomes may include tackling the risk of inadequate water quality by understanding the importance of ecosystems services as a water source and instruments of water pollution control and restoration. In such a scenario, we not only ensure or secure drinking water and human well-being, but the society at large acknowledges, through conservation, that natural ecosystems can assist in tackling climate change and disaster prevention [70] to provide long-term revenue. In addition, even in the absence of human-induced climate change, more severe drought is likely to occur in the future than has occurred in the past 30 years [71], which leads us to a scenario of reduced water availability. Creating resilient systems is one of the strategies included for short-term revenue generation, as in the case of Brazil. Using these systems leads to creating more sustainable cities and an improvement in water resource management by providing viable, cost-efficient, and effective solutions.

In addition, if solutions need to be developed and financially supported by fair pricing structures, then this kind of setting may provide stability and better acceptance by society to newer policies and arrangements. To provide this stability and ensure transparency of the water supply in urban areas, IBNET (The International Benchmarking Network for Water and Sanitation Utilities) indicators of the World Bank could help [72]. These indicators are based on a framework where the water utility must provide services to all customers at affordable prices, while controlling quality and maintaining financial incentives for its staff [73]. This analysis is based on a compilation of a databases from utilities and companies in charge of distributing water. Special considerations about the data must be evaluated prior the estimation itself, as many of the variables and performance indicators upon which IBNET reports do not fit a normal distribution but rather form a skewed distribution, for which the specific mean and the median differ. For those cases, the Blue Book recommends the median as a better representation of the performance. Some of the IBNET indicators include: water coverage, waste 
water coverage, nonrevenue water, staff productivity, operating cost coverage ratio, operation and maintenance cost, operating revenues, water consumption, collection period, affordability of water and sewage service, and cross subsidies. IBNET indicators can help to reveal management efficiency and allow for continuous updates to water structures according to their needs.

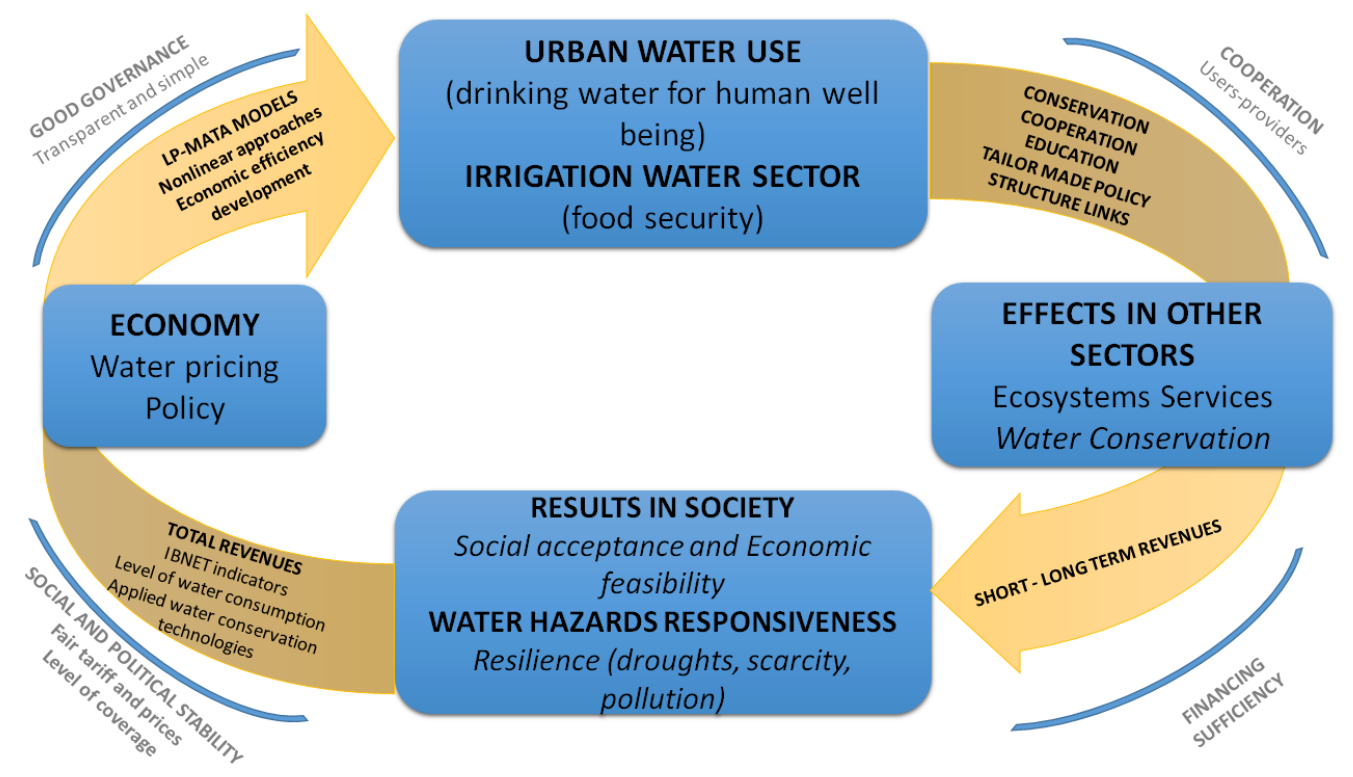

Figure 6. Suggested model for water pricing embedding water security guiding framework.

Mathematical economic models like MATA and LP are used to assess all the potential scenarios that produce negative impacts on society, economy, and the environment in the case of irrigation. It is also essential that the pricing of water services covers the costs of providing service for both operations and maintenance, as well as capital expenses including future, operations, maintenance, and capital costs. In the case of Ghana and Spain, the results of omitting the economic efficiency indicator led to water being distributed under unsustainable growth. The LP and MATA models offer a perspective on how to better implement water pricing changes under reasonable boundaries (case studies 1 and 2). Other characteristics of the suggested model are simplicity and transparency. Learning from Cochabamba (case study 4 ), wherein the water pricing policy was applied directly without consensus with the population and simplicity in the applied policies led to an unsustainable relationship between the water company and the society. The case of São Paulo (case study 3) showed how the government outlined and applied a set of combined policy strategies for drought (water scarcity) management. It was interesting to note how the population and communities reacted to managing their own consumption post-crisis. The reaction drives us to follow the loop on cooperation (users-providers) to achieve education and conservation as part of the suggested model. This highlights that the complementary policy framework must not only be applied in the face of water crisis but also in both the short and long-term policy trend, simply and transparently leveraging triggers in the policy framework and their impacts. In order to avoid conflicts and organize resilient communities, water pricing can be used as a tool for water security under specific principles and strategies, as shown in Figure 6.

As mentioned above, the water pricing policy is quite sensitive in terms of social response despite the characterization of water as an economic good, which is often considered inelastic. This implies that both simplicity and transparency are required features of the implementation of the policy, without mentioning that it must be managed in a participatory way. In the case of Cochabamba, due to the simple lack of communication between decision makers and society, the policy could not be deployed and social context was not considered (poor sectors in the metropolitan area without access to water 
and with the same rate as any other another sector). In the case of São Paulo, due to the simple intensive communication between the state government and society, unforeseen positive effects were achieved (water conservation by the population); the context of the drought crisis favored the application of the politics.

The intention of this paper was not to promote flat rates over uniform volumetric rates or privatization over public ownership. Instead, the goal was to illustrate that effective water pricing can be used in a water security framework. Water pricing is complex, and as shown, it needs to be case-specific to consider the ability of a system to respond to changes in prices. Unfortunately, there is no single water pricing structure that can achieve the water security agenda. Therefore, instead of a specific pricing system, we suggest that a water pricing policy based on current and future events is needed that considers seasonal variability, household income, and reality of each sector and ideally the vision of water security that the nations and the communities are planning to adopt.

\section{Conclusions}

Considering that water insecurity is a looming challenge to address when planning strategies for sustainable development, discussion of re-organizing water pricing, especially in countries with extreme hydro-climatic variability, is crucial. We attempted to present a set of arguments stating how smart planning of water pricing design, structure, and enforcement can serve as potential tools under the water security agenda. The water pricing case studies presented in this paper are not intended to be viewed as best practices, but rather as examples of realities on the ground in different countries. They also serve to illustrate how geographic, economic, and social diversity influence water management planning and decision-making. Water pricing can be considered as a policy tool to address some of the challenges and dimensions of the larger nexus of water security. If countries and regions are able to balance the supply-demand dynamics while assuring a water-secure future for their communities and citizens, pricing models that fit with the socio-economic and socio-political and socio-cultural complex systems will need to be carefully chosen. Recognizing this complexity in the relationship between government and society and their corresponding economic sectors, policies adjusted to the reality of each region can be implemented within the framework of water security, with strategies and tools working on systems in parallel (complementarity). Therefore, water pricing tools must not be implemented in insolation, but governments must execute them within an integral set of policies that have at least one complementary tool of social participation and cooperation (transparency and simplicity).

The critical analysis of a range of case studies makes it increasingly clear that the social parameters, environmental conditions, and cost recovery mechanisms are primary when pricing a natural resource. For example, impoverished population groups or vulnerable economic sectors should not treat water as a public or a pure economic good because of the current and predicted environmental conditions from climate change and other kinds of uncertainties. The contribution of water pricing toward the sustainable management of water resources requires large investments and financial commitments to manage direct and indirect pressures impacting the quantity and quality of water resources. We argue that these decisions should be taken in tandem with additional aspects with respect to innovations in clean water technologies, building capacity of customers/user on larger merit of valuing water, putting in place mechanisms and policies to manage and mitigate conflict, and overall, to set a long-term agenda to develop water resilient communities and nations, with sustainable management of water as normative.

Let us revisit some quick examples to set the final argument. Beginning with the Ghanaian case study, the policy did not associate water price with efficiency indexes of water consumption and therefore, instantly reflected unsustainable growth. In Spain, a fixed cost managed by the communities led to subsidized extensive agriculture with no control over efficient use of water. The São Paolo case study illustrated how urban water security was balanced in the face of the most critical drought in recent history. The Hybrid Policy—balancing the subsidy and taxation systems—demonstrated how 
the objective of conserving water resources was achieved without much altering the regular water price structures. The case study of drinking water provision in Cochabamba reflected the ineffective process of privatization that resulted in a general negative impression of the privatization approach to service provision. Finally, France's national water policy increased the use of a uniform volumetric pricing system and simultaneously improved infrastructural maintenance.

Overall, water pricing strategies and goals have the potential to tackle both physical and economic water scarcity if they are intelligently planned and implemented. Furthermore, they demonstrate that financial reserves appear to be the valuable aspect of the scenarios that can be achieved through cost-recovery from water users (case studies 3 and 5), leading to a negative response from society (case studies 1, 2 and 4). That being said, water pricing has the potential to positively trigger the water security agenda as managed water extraction, supply, and strata-based management and better investments in infrastructure can help ensure a sustainable water future. The feedback loop of smart water pricing strategies can also have positive spillover effects. For example, managed water withdrawals can help conserve services and benefits from aquatic ecosystems, whereas financial availability can ensure investments in associated aspects such as water-borne diseases and water-related disasters. The result of not considering water pricing as a tool for improved management and behavior change on future water thinking and policies leaves us in a situation where agricultural and urban water demands will continually increase without sustainable structures regulating efficient use (as explained in case study 1: insulated efficient use does not control overall irrigation consumption), conservation (as explained in case study 3: social water conservation promotion did not work on its own), maintenance, utility for expansion, and revenue. All these factors are prerequisites for countries to ensure water security, in the short-, medium-, and long-term.

Author Contributions: Conceptualization, N.N., G.A., T.A.D., and P.C.S.R.; Methodology, N.N., T.A.D., and P.C.S.R; Writing-Original Draft Preparation, P.C.S.R, N.N., T.A.D., and G.A., Writing-Review \& Editing, P.C.S.R, N.N., T.A.D., and G.A.; Visualization, T.A.D., and P.C.S.R.; G.A., N.N., Supervision, N.N. and P.C.S.R.; Project Administration, N.N. and P.C.S.R.

Funding: UNU INWEH would like to acknowledge the funding and support of Global Affairs Canada to its research, policy and development mandate, programs and projects.

Acknowledgments: We would like to thank the Ministry of Environment and Water in Bolivia for their support and collaboration.

Conflicts of Interest: The authors declare no conflict of interest.

\section{References}

1. Kejser, A. European attitudes to water pricing: Internalizing environmental and resource costs. J. Environ. Manag. 2016, 183, 453-459. [CrossRef] [PubMed]

2. Cook, C.; Bakker, K. Water security: Debating an emerging paradigm. Glob. Environ. Chang. 2012, 22, 94-102. [CrossRef]

3. Ministerial Declaration of the Hague on Water Security in the 21st Century. Available online: http://www. worldwatercouncil.org/sites/default/files/World_Water_Forum_02/The_Hague_Declaration.pdf (accessed on 5 August 2018).

4. UN-Water. Analytical Brief on Water Security and the Global Water Agenda: A UN-Water Analytical Brief. 2013. Available online: https://collections.unu.edu/eserv/UNU:2651/Water-Security-and-the-GlobalWater-Agenda.pdf (accessed on 8 October 2017).

5. Mehta, P.; Nagabhatla, N. Without Water, Nothing Is Secure; UNU-INWEH Policy Brief; United Nations University Institute for Water Environment and Health: Hamilton, ON, Canada, 2017.

6. Reddy, V.R. Water pricing as a demand management option: Potentials, problems, and prospects. In Strategic Analyses of the National River Linking Project (NRLP) of India, Series 3-Promoting Irrigation Demand Management in India: Potentials, Problems, and Prospects; Saleth, R.M., Ed.; International Water Management Institute: Colombo, Sri Lanka, 2009; pp. 25-46.

7. Wehn, U.; Montalvo, C. Exploring the dynamics of water innovation: Foundations for water innovation studies. J. Clean. Prod. 2018, 171, S1-S19. [CrossRef] 
8. Frederick, K.D. Balancing Water Demands with Supplies: The Role of Management; The World Bank: Washington, DC, USA, 1993; Available online: http://documents.worldbank.org/curated/en/321231468766544380/ Balancing-water-demands-with-supplies-the-role-of-management-in-a-world-of-increasing-scarcity (accessed on 1 April 2017).

9. Ahmad, M. Water pricing and markets in the Near East: Policy issues and options. Water Policy 2000, 2, 229-242. [CrossRef]

10. World Economy Forum (WEF). Global Risks 2017. Available online: http:/ / reports.weforum.org/globalrisks-2017/ part-1-global-risks-2017/ (accessed on 20 October 2017).

11. UN-Water. What Is Water Security? Infographic. Available online: http:/ /www.unwater.org/publications/ water-security-infographic/ (accessed on 10 September 2017).

12. Sokolow, S.; Godwin, H.; Cole, B.L. Impacts of Urban Water Conservation Strategies on Energy, Greenhouse Gas Emissions, and Health: Southern California as a Case Study. Am. J. Public Health 2016, 106, 941-948. [CrossRef] [PubMed]

13. Evans, R.G.; Sadler, E.J. Methods and technologies to improve efficiency of water use. Water Resour. Res. 2008, 44. [CrossRef]

14. Environmental Protection Agency (EPA). Cases in Water Conservation: How Efficiency Programs Help Water Utilities Save Water and Avoid Costs. Available online: https:/ /www.epa.gov/sites/production/ files/2017-03/documents/ws-cases-in-water-conservation.pdf (accessed on 10 October 2017).

15. Linstead, C.L. The contribution of improvements in irrigation efficiency to environmental flows. Front. Environ. Sci. 2018, 6. [CrossRef]

16. Shiklomanov, I.A. World Water Resources and Water Use: Modern Assessment and Outlook for the 21st Century. Available online: http:/ / documentos.dga.cl/PHI710.pdf (accessed on 31 August 2018).

17. World Meteorological Organization (WMO). International Conference on Water and the Environment: Development Issues for the 21st Century; ICWE Secretariat, World Meteorological Organization: Dublin, Ireland, 1992.

18. McNeill, D. Water as an economic good. Nat. Resour. Forum 1998, 22, 253-261. [CrossRef]

19. Perry, C.J.; Seckler, D.; Rock, M.T.; Seckler, D.W. Water as an Economic Good: A Solution, or a Problem? Research Report 014; International Irrigation Management Institute: Colombo, Sri Lanka, 1997.

20. Briscoe, J. Water as an Economic Good: The Idea and What it Means in Practice. In Proceedings of the World Congress of the International Commission on Irrigation and Drainage, Cairo, Egypt, September 1996; The World Bank: Washington, DC, USA, 1996.

21. Banovec, P.; Domadenik, P. Pricing Approaches in the Case of Cross-Border Water Supply. Procedia Eng. 2016, 162, 601-610. [CrossRef]

22. Kanakoudis, V.; Papadopoulou, A.; Tsitsifli, S. Domestic water pricing in Greece: mean net consumption cost versus mean payable amount. Fresenius Environ. Bull. 2014, 23, 2742-2749.

23. Tsitsifli, S.; Gonelas, K.; Papadopoulou, A.; Kanakoudis, V.; Kouziakis, C.; Lappos, S. Socially fair drinking water pricing considering the Full Water Cost recovery principle and the Non-Revenue Water related cost allocation to the end users. Desalin. Water Treat. 2017, 99, 72-82. [CrossRef]

24. Renzetti, S.; Dupont, D.P. Water pricing in Canada: Recent Developments. In Water Pricing Experiences and Innovations; Springer International Publishing: New York, NY, USA, 2015; pp. 63-81.

25. Donnelly, K.; Christian-Smith, J. An Overview of the "New Normal" and Water Rate Basics; Pacific Institute: Oakland, CA, USA, 2011; Available online: http:/ / pacinst.org/wp-content/uploads/2013/06/pacinst-newnormal-and-water-rate-basics.pdf (accessed on 1 September 2017).

26. Bogaert, S.; Vandenbroucke, D.; Dworak, T.; Berglund, M.; Interwies, E.; Görlitz, S.; Schmidt, G.; Álvaro, M.H. The Role of Water Pricing and Water Allocation in Agriculture in Delivering Sustainable Water Use in Europe-Final Report; Project Number 11589; Arcadis: Brussels, Belgian. Available online: http:/ /www. enorasis.eu/uploads/files/Water\%20Governance/role_water_pricin.pdf (accessed on 10 May 2017).

27. Vander Ploeg, C.G. Water Pricing: Seizing a Public Policy Dilemma by the Horns: Canadian Water Policy Backgrounders; Canada West Foundation: Calgary, AB, Canada, 2011; Available online: http:/ / cwf.ca/wpcontent/uploads/2015/11/CWF_WaterBackgrounder7_SEP2011.pdf (accessed on 3 May 2017). 
28. Mostert, E.; Van Beek, E.; Bouman, N.W.M.; Hey, E.; Savenije, H.H.G.; Thissen, W.A.H. River basin management and planning. In the International Workshop on River Basin Management; Technical Documents in Hydrology No. 31; The United Nations Educational, Scientific and Cultural Organization (UNESCO): The Hague, The Netherlands, 1999; pp. 24-55.

29. Green, C.H. The Handbook of Water Economics: Principles and Practice; John Wiley \& Sons: Chichester, West Sussex, England, 2003; ISBN 0-471-98571-6.

30. Ahlers, R. Fixing and Nixing: The politics of water privatization. Rev. Radic. Polit. Econ. 2010, 42, $213-230$. [CrossRef]

31. Zaag, P.; Savenije, H.H.G. Water as an Economic Good: The Value of Pricing and the Failure of Markets; Value of Water Research Report Series No. 19; UNESCO-IHE: Delft, The Netherlands, 2006.

32. Chambers, R.; Pacey, A.; Thrupp, L.A. Farmer First: Farmer Innovation and Agricultural Research; Intermediate Technology Publications: London, UK, 1989; ISBN 1853390070.

33. Berbel, J.; Gómez-Limón, J.A. The impact of water-pricing policy in Spain: An analysis of three irrigated areas. Agric. Water Manag. 2000, 43, 219-238. [CrossRef]

34. Elnaboulsi, J.C. An incentive water pricing policy for sustainable water use. Environ. Resour. Econ. 2009, 42, 451-469. [CrossRef]

35. Kanakoudis, V.; Tsitsifli, S.; Gonelas, K.; Papadopoulou, A.; Kouziakis, C.; Lappos, S. Determining a Socially Fair Drinking Water Pricing Policy: The Case of Kozani, Greece. Procedia Eng. 2016, 162, 486-493. [CrossRef]

36. Aidam, P.W. The impact of water-pricing policy on the demand for water resources by farmers in Ghana. Agric. Water Manag. 2015, 158, 10-16. [CrossRef]

37. Hailu, D.; Osorio, R.G.; Tsukada, R. Privatization and renationalization: What went wrong in Bolivia's water sector? World Dev. 2012, 40, 2564-2577. [CrossRef]

38. The State of the Ghanaian Economy Report, 2012; Institute of Statistical, Social and Economic Research (ISSER): Legon, Ghana, 2013.

39. World Bank. 3RD GHANA ECONOMIC UPDATE Agriculture as an Engine of Growth and Jobs Creation. 2018. Available online: http:/ / documents.worldbank.org/curated/en/113921519661644757/pdf/123707REVISED-Ghana-Economic-Update-3-13-18-web.pdf (accessed on 31 August 2018).

40. Drechsel, P.; Keraita, B. Irrigated Urban Vegetable Production in Ghana: Characteristics, Benefits, and Risks, 2nd ed.; International Water Management Institute: Colombo, Sri Lanka, 2014. [CrossRef]

41. Food and Agriculture Sector Development Policy (FASDEP); The Ministry of Food and Agriculture (MOFA): Accra, Ghana, 2012.

42. Botwe, B.O.; Ntow, W.J.; Kelderman, P.; Drechsel, P.; Carboo, D.; Nartey, V.K.; Gijzen, H.J. Pesticide residues contamination of vegetables and their public health implications in Ghana. J. Environ. Issues Agric. Dev. Ctries. 2011, 3, 10.

43. Water Resource Management Policy Paper; Report Number 12335; The World Bank: Washington, DC, USA, 1993.

44. Molle, F.; Berkoff, J. Water pricing in irrigation: Mapping the debate in the light of experience. In Irrigation Water Pricing: The Gap between Theory and Practice; Molle, F., Berkoff, J., Eds.; The Centre for Agriculture and Bioscience International (CABI) Publishing: Wallingford, CT, USA, 2007; pp. 21-93.

45. Obour, P.B.; Dadzie, F.A.; Kristensen, H.L.; Rubæk, G.H.; Kjeldsen, C.; Saba, C.K.S. Assessment of farmers' knowledge on fertilizer usage for peri-urban vegetable production in the Sunyani Municipality, Ghana. Resour. Conserv. Recycl. 2015, 103, 77-84. [CrossRef]

46. Amponsah, O.; Vigre, H.; Schou, T.W.; Boateng, E.S.; Braimah, I.; Abaidoo, R.C. Assessing low-quality water use policy framework: The Case study from Ghana. Resour. Conserv. Recycl. 2015, 97, 1-15. [CrossRef]

47. Gerard, F.; Marty, I.; Lancon, F.; Versapuech, M. Measuring the Effects of Trade Liberalization: The Multilevel Analysis Tool for Agriculture; Working Papers 32721; Regional Coordination Center for Research and Development of Coarse Grains, Pulses, Roots and Tuber Crops in the Humid Topics of Asia and the Pacific (The CGPRT Center): Bogor, Indonesia, 1998; p. 171.

48. Gilbertson, D.D. Runoff (floodwater) farming and rural water supply in arid lands. Appl. Geogr. 1986, 6, 5-11. [CrossRef]

49. A SABESP Está Prorrogando o Programa de Incentivo à Redução de Consumo. Available online: http: / / site.sabesp.com.br/site/interna/Default.aspx?secaoId=544 (accessed on 22 December 2017). 
50. Banovec, P.; Domadenik, P. Paying too much or too little? Pricing approaches in the case of cross-border water supply. Water Sci. Technol. Water Supply 2017, 18, 577-585. [CrossRef]

51. Zeitoun, M.; Lankford, B.; Krueger, T.; Forsyth, T.; Carter, R.; Hoekstra, A.Y.; Taylor, R.; Varis, O.; Cleaver, F.; Boelens, R.; et al. Reductionist and integrative research approaches to complex water security policy challenges. Glob. Environ. Chang. 2016, 39, 143-154. [CrossRef]

52. Press Release: IMF Approves Three-Year Arrangement under the ESAF for Bolivia. Available online: https: / www.imf.org/en/News/Articles/2015/09/14/01/49/pr9841 (accessed on 17 July 2017).

53. Bechtel Perspective on the Aguas del Tunari Water Concession in Cochabamba, Bolivia. Available online: http:/ / www.bechtel.com/files/perspective-aguas-del-tunari-water-concession/ (accessed on 16 May 2017).

54. Nickson, A.; Vargas, C. The limitations of water regulation: The failure of the Cochabamba concession in Bolivia. Bull. Lat. Am. Res. 2002, 21, 99-120. [CrossRef]

55. Dige, G.; De Paoli, G.; Strosser, P.; Anzaldua, G.; Ayres, A.; Lange, M.; Lago, M.; Oosterhuis, F.H.; Hrabar, M.; Navrud, S. Assessment of Cost Recovery through Water Pricing; Technical report No. 16/2013.; European Environment Agency: Copenhagen, Denmark, 2013. [CrossRef]

56. Angel, J. Potential Impacts of Climate Change on Water Availability. Available online: http://www.isws. illinois.edu/iswsdocs/wsp/climate_impacts_012808.pdf (accessed on 20 June 2017).

57. Peredo-Beltran, E. Water, Privatization and Conflict: Women from the Cochabamba Valley; Heinrich Boll Foundation: Berlin, Germany, 2004.

58. Shultz, J. The Cochabamba Water Revolt, and Its Aftermath. In Dignity and Defiance: Stories from Bolivia's Challenge to Globalization; Shultz, J., Draper, M., Eds.; University of California Press: Oakland, CA, USA, 2008.

59. Marston, A. The scale of informality: Community-run water systems in peri-urban Cochabamba, Bolivia. Water Altern. 2014, 7, 72-88.

60. Bolivia Water Management: A Tale of Three Cities; Report Number 222; The World Bank: Washington, DC, USA, 2002.

61. Chong, E.; Huet, F.; Saussier, S.; Steiner, F. Public-private partnerships and prices: Evidence from water distribution in France. Rev. Ind. Organ. 2006, 29, 149-169. [CrossRef]

62. Montginoul, M.; Loubier, S.; Barraqué, B.; Agenais, A.L. Water pricing in France: Toward more incentives to conserve water. In Water Pricing Experiences and Innovations; Springer International Publishing: New York, NY, USA, 2015; pp. 139-160.

63. Demouliere, R.; Bensaid Schemba, J.; Berger, J.L.; Ait Kaci, A.; Rougier, F. Public water supply and sanitation services in France: Economic, social and environmental data. Available online: /http://www.fp2e.org/ userfiles / files / publication/etudes/Etude\%20FP2E-BIPE\%202012_VA.pdf (accessed on 8 August 2017).

64. Forrer, D.A.; Boudreau, J.; Boudreau, E.; Garcia, S.; Nugent, C.; Allen, D.; Lubin, A.C. The Effects of Water Utility Pricing on Low Income Consumers. J. Int. Energy Policy 2016, 5, 9-18. [CrossRef]

65. European Commission. Science for Environment Policy: Pricing policies for efficient water management. Available online: http:/ / ec.europa.eu/environment/integration/research/newsalert/pdf/307na6_en.pdf (accessed on 3 July 2017).

66. Dinar, A. The Political Economy of Water Pricing Reforms; The World Bank: Washington, DC, USA, 2000. Available online: http:/ / documents.worldbank.org/curated/en/199301468771050868/pdf/multi-page.pdf (accessed on 1 September 2017).

67. Yepes, G. Los Subsidios Cruzados en los Servicios de Agua Potable y Saneamiento. Available online: https:/ / publications.iadb.org/handle/11319/5013 (accessed on 3 July 2017).

68. Tiger, M.; Hughes, J.; Eskaf, S. Designing Water Rate Structures for Conservation \& Revenue Stability; University of North Carolina Environmental Finance Center and Sierra Club, Lone Star Chapter: Chapel Hill, NC, USA; Austin, TX, USA, 2014.

69. Deybe, D. Can agricultural sector models be a tool for policy analysis? An application for the case of Burkina Faso. Agric. Syst. 1998, 58, 367-380. [CrossRef]

70. Van den Berg, C.; Danilenko, A. The IBNET Water Supply and Sanitation Performance Blue Book: The International Benchmarking Network for Water and Sanitation Utilities Databook; The World Bank: Washington, DC, USA, 2011.

71. Danilenko, A.; Van den Berg, C.; Macheve, B.; Moffitt, L.J. The IBNET Water Supply and Sanitation Blue Book 2014: The International Benchmarking Network for Water and Sanitation Utilities Databook; The World Bank: Washington, DC, USA, 2014. 
72. Kennemore, A.; Weeks, G. Twenty-First Century Socialism? The Elusive Search for a Post-Neoliberal Development Model in Bolivia and Ecuador. Bull. Lat. Am. Res. 2011, 30, 267-281. [CrossRef]

73. Spronk, S. Roots of Resistance to Urban Water Privatization in Bolivia: The "New Working Class," the Crisis of Neoliberalism, and Public Services. Int. Labor Work. Cl. History 2007, 71, 8-28. [CrossRef] 